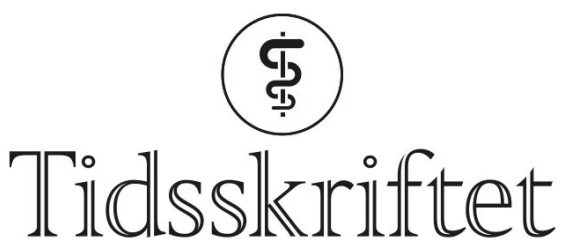

DEN NORSKE LEGEFORENING

\title{
Fastlegers syn på legemiddelassistert rehabilitering
}

ORIGINALARTIKKEL

\section{HELGE WAAL}

Helge Waal (f. 1940) er spesialist i psykiatri, professor emeritus og medisinskfaglig rådgiver ved Senter for rus- og avhengighetsforskning. Han har vært leder for Seksjon for kliniske rusmiddelproblemer.

Forfatter har fylt ut ICMJE-skjemaet og oppgir ingen interessekonflikter.

Email: helge.waal@medisin.uio.no

Senter for rus- og avhengighetsforskning

Institutt for klinisk medisin

Universitet i Oslo

og

Klinikk for rus og avhengighet

Oslo universitetssykehus

\section{METTE BREKKE}

Mette Brekke (f. 1953) er spesialist i allmennmedisin. Hun er professor ved Avdeling for allmennmedisin, Institutt for helse og samfunn, Universitetet i Oslo og fastlege ved Kurbadet legesenter i Oslo.

Forfatter har fylt ut ICMJE-skjemaet og oppgir ingen interessekonflikter.

Avdeling for allmennmedisin

Institutt for helse og samfunn

Universitetet i Oslo

\section{THOMAS CLAUSEN}

Thomas Clausen (f. 1972) er professor ved Senter for rus- og avhengighetsforskning, Universitetet i Oslo, med særlig interesse for LAR-behandling og ulike behandlingstilnærminger og effekt i behandlingen av rusavhengighet. Han er nasjonal ekspert for "Stoffrelatert dødelighet» $\mathrm{i}$ The European Monitoring Centre for Drugs and Drug Addiction (EMCDDA).

Forfatter har fylt ut ICMJE-skjemaet og oppgir ingen interessekonflikter.

Senter for rus- og avhengighetsforskning

Institutt for klinisk medisin

Universitetet i Oslo

\section{MORTEN LINDBAKK}

Morten Lindbæk (f. 1950) er spesialist i allmennmedisin og professor ved Universitetet i Oslo samt fastlege i Stokke kommune og leder av Antibiotikasentret for primærmedisin.

Forfatter har fylt ut ICMJE-skjemaet og oppgir ingen interessekonflikter.

Antibiotikasenteret for primærmedisin

Institutt for helse og samfunn

Universitetet i Oslo 
Judith Rosta (f. 1968) er M.A./ph.d. og forsker ved Legeforeningens forskningsinstitutt. Hun har 13 års erfaring med forskning om legers helse og arbeidsforhold, bl.a. initierte hun og ledet den første nasjonale spørreskjemaundersøkelse blant sykehusleger i Tyskland.

Forfatter har fylt ut ICMJE-skjemaet og oppgir ingen interessekonflikter.

Legeforeningens forskningsinstitutt

\section{IVAR SKEIE}

Ivar Skeie (f. 1952) er spesialist i allmennmedisin. Han er konstituert overlege ved DPS Gjøvik poliklinikk, arbeidsfelt rus og legemiddelassistert rehabilitering. Er også stipendiat ved Senter for rus- og avhengighetsforskning, Universitetet i Oslo med prosjektet «Somatisk sykelighet hos opioidavhengige før, under og etter LAR». Han leder referansegruppen for rusmedisin i Norsk forening for allmennmedisin.

Forfatter har fylt ut ICMJE-skjemaet og oppgir ingen interessekonflikter.

Senter for rus- og avhengighetsforskning

Institutt for klinisk medisin

Universitet i Oslo

og

Distriktspsykiatrisk senter, Gjøvik

Sykehuset Innlandet

\section{OLAF GJERLØW AASLAND}

Olaf Gjerløw Aasland (f. 1944) er leder av Legeforeningens forskningsinstitutt og professor ved Institutt for helse og samfunn, Universitetet i Oslo. Han har vært overlege i Statens edruskapsdirektorat og sittet i WHOs Expert Advisory Panel on Drug Dependence and Alcohol Problems.

Forfatter har fylt ut ICMJE-skjemaet og oppgir ingen interessekonflikter.

Legeforeningens forskningsinstitutt

og

Avdeling for helseledelse og helseøkonomi

Institutt for helse og samfunn

Universitetet i Oslo

\section{BAKGRUNN.}

Legemiddelassistert rehabilitering (LAR) er en tverrfaglig trepartsmodell for behandling av opioidavhengighet. Modellen forutsetter samhandling mellom allmennlegene, sosialtjenesten og spesialisthelsetjenesten. Den innskrenker i noen grad legenes faglige autonomi. Undersøkelsen tar sikte på å undersøke fastlegers holdninger til modellen og spesielt erfaringene til dem som har deltatt aktivt i den.

\section{MATERIALE OG METODE.}

Et elektronisk spørreskjema (Questback) ble sendt til norske fastleger på grunnlag av Legeforeningens medlemsregister. Respondentene ble spurt om generell oppfatning av legemiddelassistert rehabilitering. De som hadde hatt slike pasienter ble spurt om sine erfaringer og vurderinger basert på 22 utsagn.

\section{RESULTATER.}

1165 leger (34\%) besvarte undersøkelsen. 155 (13\%) var negative, 395 (34\%) nøytrale, og 604 (53\%) positive til legemiddelassistert rehabilitering. 683 (59\%) hadde erfaring som LARlege. Disse hadde ca. 50 \% av landets LAR-pasienter i behandling. Trepartsmodellen har betydelig støtte. Svært få ønsker større autonomi. Majoriteten støtter også den store vekten på kontroll, selv om noen, særlig eldre leger med LAR-erfaring, mener at urinkontroller bør kunne erstattes med personlig kontakt.

\section{FORTOLKNING.}

Legemiddelassistert rehabilitering ble hovedsakelig vurdert positivt av norske fastleger i dette utvalget. Det var liten opposisjon mot legerollen i modellen, selv om den i noen grad innskrenker den enkelte leges autonomi. 


\section{Tabell}

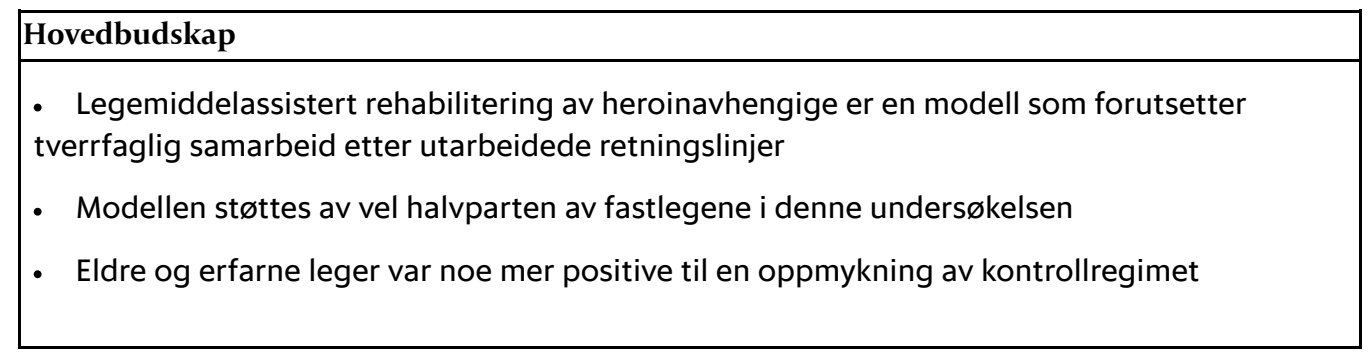

Substitusjonsbehandling med metadon eller buprenorfin er i dag den vanligste behandlingen for heroinavhengighet (1). I Norge ble behandlingen etablert som legemiddelassistert rehabilitering (LAR) i 1997. Modellen har vært evaluert flere ganger (2) -(5). Helsedirektoratet utga retningslinjer bygd på særlige forskrifter i 2010 (ㅁ), men den grunnleggende modellen er uendret. Vurdering av indikasjon, valg av medikamenttype og innstilling på optimal dosering skal skje i spesialisthelsetjenesten. Allmennlegene har en sentral rolle i behandlingen, men kan ikke selvstendig iverksette den. Det forutsettes samarbeid med den kommunale sosialtjenesten, og behandlingen skal bygge på bruk av ansvarsgrupper og tiltaksplan. Den medfører altså bestemte krav til deltakelse fra legenes side og en viss innskrenkning i deres frie behandlingsvalg.

Medikamentell vedlikeholdsbehandling med metadon ble utviklet i USA, med strenge krav til kontroll og vekt på spesialiserte sentre. I dag er behandlingen ulikt utformet internasjonalt. Den norske modellen har en spesiell ansvarsdeling mellom spesialisttiltak og allmennleger.

Innføringen av fastlegeordningen i 2001 og endringer i kommunehelsetjenesteloven og spesialisthelsetjenesteloven i 2002 har sammen med rusreformene fra 2004 gitt leger en viktigere rolle i rusbehandlingen. Norske legers syn på denne utviklingen og på legemiddelassistert rehabilitering ble undersøkt i spørreskjemaundersøkelser til et legepanel i 2000 og 2006 (7.). Majoriteten var positiv til reformene, og $53 \%$ hadde dessuten et positivt syn på substitusjonsbehandling, både i 2000 og i 2006. I 2000 var $45 \%$ negative til selvå forskrive metadon/buprenorfin, mens denne andelen var $33 \%$ i 2006.

I januar 2010 var 5383 pasienter i legemiddelassistert rehabilitering. 3500 (65\%) av disse ble behandlet av allmennlege som samarbeidet med LAR-team (므). Ett år senere var 6015 pasienter i LAR-behandling. 4 ogo (68\%) av disse fikk LAR-medikamentet forskrevet av sin fastlege (9.). Et betydelig antall norske leger er derfor deltakere i et trepartssamarbeid med sosialtjenesten (NAV) og spesialisthelsetjenesten. Enkelte leger har vært sterkt kritiske til

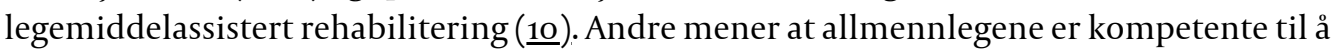
ha et større ansvar innenfor modellen (11). Fra kriminologisk og rettsvitenskapelig hold har det kommet sterk kritikk mot et autoritært «metadontilsyn» (12).

I dag er legemiddelassistert rehabilitering blitt en integrert del av helsetjenesten, erfaringsgrunnlaget er bredere og debatten er mer nyansert. I denne studien ønsket vi å undersøke om utviklingen har endret norske allmennlegers syn på denne behandlingsformen og hvordan leger med LAR-erfaring vurderer den norske modellen med ansvarsdeling og trepartssamarbeid. Dette er viktig både for videre utvikling av legemiddelassistert rehabilitering og for diskusjonene om samhandlingsmodeller for sammensatte helsetjenester.

\section{Materiale og metode}


Et utvalg på 3770 fastleger ble trukket fra Legeforeningens medlemsregister i november 2009. Dette var alle i registeret på dette tidspunktet minus et tilfeldig utvalg på 500 som ble brukt i en annen studie. Disse legene fikk i juni 2010 en e-post med lenke til et elektronisk spørreskjema (QuestBack) og informasjon om at Senter for rus- og avhengighetsforskning ved Universitetet i Oslo (SERAF), Referansegruppe for rusmedisin i Norsk forening for allmennmedisin (Legeforeningen) og Legeforeningens forskningsinstitutt sto bak undersøkelsen. Datainnsamlingen varte frem til 13.9. 2010, med fire purringer. Undersøkelsen var godkjent av Norsk samfunnsvitenskapelig datatjeneste.

Spørreskjemaet var todelt. Første del inneholdt spørsmål om holdning til og meninger om legemiddelassistert rehabilitering. De som hadde deltatt i slik behandling, fylte ut del 2 med 22 utsagn om modellen, uformet på grunnlag av debatten i faglige fora. De generelle vurderingene ble undersøkt med en tredelt verdiskala (negativ-nøytral-positiv) og de spesifikke meningene med en femdelt Lickert-skala fra 1 (helt uenig) til 5 (helt enig). Undersøkelsen var anonym, men vi spurte om kjønn, alder, listelengde, fylke og spesialisering i allmennmedisin samt antall LAR-pasienter totalt og på svartidspunktet.

Resultatene presenteres primært deskriptivt. Vi benytter prosentandeler og gjennomsnittsverdier til å beskrive tendens og gruppesammenlikninger og logistiske regresjoner til å beskrive samtidige effekter. De fire avhengige variablene i regresjonsanalysene var alle på en ordinal skala fra $1-5$. Oddsratene representerer endringen i assosiasjonen som finner sted ved å bevege seg en ordinal plass på skalaen, for eksempel fra 1 til 2. En odds større enn 1.0 indikerer dermed en signifikant assosiasjon mellom den uavhengige variabelen og større tilslutning til holdningsutsagnet i modellen. Statistisk signifikans er testet med khikvadrat eller $95 \%$ konfidensintervall. Alle analyser er gjort med Predictive Analytics SoftWare Statistics (PASW), versjon 18.

\section{Resultater}

Av de 3770 inviterte fastlegene brukte 243 avmeldingslenken. 120 spørreskjemaer kom i retur pga. feil e-postadresse. Reell svarprosent ble da 34 (1 165/3 407). Av disse var 411 (35\%) kvinner og $750(65 \%)$ menn (ubesvart = 4). Respondentene hadde arbeidet gjennomsnittlig 16,2 år som fastleger. Majoriteten var spesialister eller under spesialisering $i$

allmennmedisin. Gjennomsnittlig antall listepasienter var 1191.

$883(76 \%)$ leger hadde erfaring med systematisk behandling og oppfølging av pasienter med rusmiddelproblemer i sin alminnelighet. $321(28 \%)$ hadde ikke henvist noen pasient til spesialisert rusbehandling det siste året, mens $766(66 \%)$ hadde gjort det «noen få ganger». Bare 72 (6\%) hadde henvist månedlig eller oftere. 683 (59\%) av respondentene hadde noen gang deltatt i LAR-behandling. Disse er kalt LAR-leger i denne artikkelen. 149 (22 \%) av LARlegene hadde på svartidspunktet ikke LAR-pasienter. De andre 534 (78\%) hadde til sammen 2028 LAR-pasienter. Dette var på undersøkelsestidspunktet ca. $53 \%$ av alle LAR-pasienter i behandling hos allmennleger beregnet ut fra middeltallet mellom antallet ved begynnelsen og slutten av året. $445(65 \%)$ av LAR-legene hadde færre enn seks LARpasienter, 215 hadde 6-10 LAR-pasienter og 23 leger hadde flere enn ti LAR-pasienter. Fem leger hadde flere enn 20 LAR-pasienter, derav tre 30 eller flere. Én lege hadde 70 pasienter og en 85 . Gjennomsnittet var noe under fire LAR-pasienter per lege.

Utvalgets representativitet når det gjelder alder, kjønn, arbeidsfylke og spesialisering i allmennmedisin fremgår av tabell 1 . Respondentene og LAR-legene skilte seg lite fra fastlegegruppen som helhet med unntak av en viss geografisk skjevfordeling og noe høy andel spesialister i allmennmedisin. LAR-legene skilte seg ikke fra alle respondentene på annen måte enn ved at noen flere var fra østlandsområdet.

\section{Tabell 1}


Utvalgets representativitet når det gjelder kjønn, alder, region og spesialitet

\begin{tabular}{|c|c|c|c|}
\hline & \multicolumn{2}{|c|}{ Våre respondenter } & \multirow[t]{2}{*}{$\begin{array}{c}\text { Alle fastleger } \\
\text { i november } 2009\end{array}$} \\
\hline & Alle & $\begin{array}{l}\text { Leger med LAR- } \\
\text { erfaring }\end{array}$ & \\
\hline Antall & 1165 & 683 & 4205 \\
\hline \multirow[t]{2}{*}{ Kvinneandel, prosent (95 \% KI) } & $35,4(32,6-38,0)$ & $30,6(27,1-34,1)$ & 37,1 \\
\hline & [Ubesvart 4] & [Ubesvart 0] & \\
\hline \multicolumn{4}{|l|}{ Alder, prosent $(95 \% \mathrm{KI})$} \\
\hline$\leq 40$ år & $31,4(28,5-33,9)$ & $31,2(27,7-34,7)$ & 29,9 \\
\hline 41-55 år & $39,0(36,1-41,7)$ & $39,3(35,6-42,9)$ & 39,0 \\
\hline \multirow[t]{2}{*}{$>55 a ̊ r$} & $29,6(26,9-32,1)$ & $29,5(26,1-32,9)$ & 31,1 \\
\hline & [Ubesvart 4] & [Ubesvart 1] & \\
\hline \multicolumn{4}{|l|}{ Arbeidsfylke, prosent (95\% KI) } \\
\hline $\begin{array}{l}\text { Østfold, Akershus, Oslo, Hedmark, } \\
\text { Oppland }\end{array}$ & $35,1(30,5-39,4)$ & $44,5(40,8-48,3)$ & 32,0 \\
\hline $\begin{array}{l}\text { Buskerud, Vestfold, Telemark, Aust- } \\
\text { og Vest-Agder }\end{array}$ & $9,1(5,3-12,9)$ & $18,8(15,9-21,7)$ & 15,2 \\
\hline $\begin{array}{l}\text { Rogaland, Hordaland, Sogn og } \\
\text { Fjordane }\end{array}$ & $21,8(16,7-26,9)$ & $17,2(14,5-18,9)$ & 19,7 \\
\hline $\begin{array}{l}\text { Møre og Romsdal, Sør-Trøndelag, } \\
\text { Nord-Trøndelag }\end{array}$ & $13,4(8,0-18,8)$ & $12,3(9,8-14,8)$ & 14,0 \\
\hline \multirow[t]{2}{*}{ Nordland, Troms, Finnmark } & $10,8(5,4-16,2)$ & $9,9(7,7-12,1)$ & 11,1 \\
\hline & [Ubesvart 9] & [Ubesvart 3] & \\
\hline \multicolumn{4}{|l|}{$\begin{array}{l}\text { Spesialist i allmennmedisin, } \\
\text { prosent }(95 \% \mathrm{KI})\end{array}$} \\
\hline Ikke spesialist & $5,9(4,3-6,9)$ & $5,4(3,7-7,1)$ & - \\
\hline Under spesialisering & $27,9(25,2-30,4)$ & $28,7(25,3-32,1)$ & - \\
\hline \multirow[t]{2}{*}{ Spesialist } & $66,1(63,1-68,5)$ & $65,9(62,3-69,5)$ & 56,4 \\
\hline & [Ubesvart 5] & [Ubesvart 0] & \\
\hline
\end{tabular}

\section{HOLDNINGER TIL LAR}

Holdningene til substitusjonsbehandling (LAR) varierte: 155 (13\%) var negative, 395 (34\%) var nøytrale, mens 607 (53\%) beskrev en positiv holdning. 414 (36\%) «kunne ikke selv tenke seg å forskrive metadon eller buprenorfin». 572 (49\%) var positive til å delta i slik behandling, mens 172 (15\%) var usikre.

\section{ERFARINGER SOM LAR-LEGE}

Gruppen med erfaring som LAR-lege ble spurt om hvordan det var å være lege for LARpasienter. 252 (37\%) svarte at det var positivt, 261 (38\%) var nøytrale, mens 167 (25\%) vurderte det som negativt. LAR-legenes skåringer for de spesifikke utsagnene i del 2 fremgår av figur 1. Flertallet verdsetter samarbeid på dette feltet, og trepartsmodellen har 
stor tilslutning i dette utvalget. Få ønsker å ha behandlingsansvar alene og svært få vurderer spesialisthelsetjenesten som en hindring. Legene i utvalget støtter i hovedsak kontrollen av behandlingen og begrensningene i legenes autonomi. Få LAR-leger mener at ansvarsgruppene tar for mye tid eller at de ofte er dårlig ledet. Utsagnet om at legemiddelassistert rehabilitering mest er skadereduksjon deler svarerne i to like grupper med vekt på delvis enig og delvis uenig. Det samme gjør spørsmålet om hvorvidt legene opplever at spesialisthelsetjenesten er til hjelp.

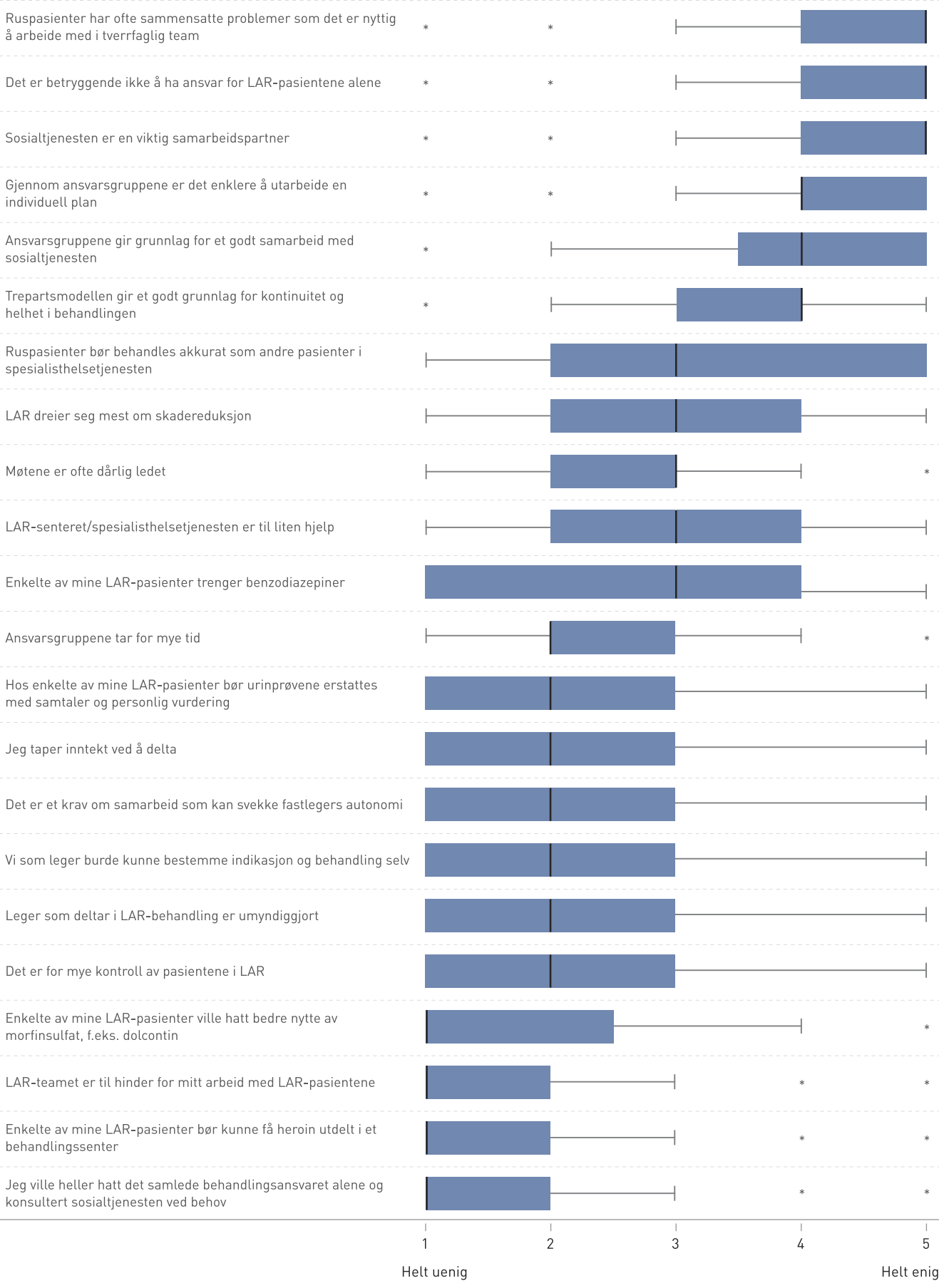

Figur 1 Medianfordelingen av svarene på en linje mellom $1=$ helt uenig og $5=$ helt enig. Medianen er markert med en tykk vertikal strek. Boksene - de horisontale rektangleneviser prosenttilområdet fra $25 \%$ til $75 \%$. De tynne linjene markerer svar over og under disse prosentilområdene. Avvikende enkeltsvar er markert med asterisk. Spørsmålene er rangert etter fallende medianverdier og derfor etter grad av enighet/uenighet Tabell 2 viser effekten av listelengde, spesialiststatus, helseregion, alder og kjønn på fire forskjellige forhold ved LAR-medvirkning. Verdsettingen av å delta i legemiddelassistert rehabilitering er i hovedsak uavhengig av kjønn, listelengde, erfaringer med 
rusbehandling og spesialiststatus. Yngre leger tenderer mot mer negativ holdning til modellen, mens de som har hatt mange LAR-pasienter er mer positive. Samarbeidet med spesialisthelsetjenesten vurderes mer positivt i Midt-Norge og i de fylkene som tidligere utgjorde Helseregion Sør. De som har mange LAR-pasienter og de som arbeider i Nord- og Midt-Norge er i større grad uenige i at legemiddelassistert rehabilitering mest er skadereduksjon. Det er noe større tilslutning til at enkelte LAR-pasienter trenger benzodiazepiner blant dem som har hatt mange LAR-pasienter og blant dem som arbeider i Nord-Norge. Økende antall LAR-pasienter på lista er assosiert med økende tilfredshet med å være LAR-lege og med større åpenhet for å forskrive benzodiazepiner, men mindre enighet $\mathrm{i}$ at legemiddelassistert rehabilitering er mest skadereduksjon.

\section{Tabell 2}

Faktorer som påvirker holdninger til legemiddelassistert rehabilitering (LAR) blant leger i Norge. Ordinal logistisk regresjon i fire separate modeller med identiske kovarianter. Oddsrate ( $95 \% \mathrm{KI})$. Variablene «listelengde» og «antall LAR-pasienter siste år» er kontinuerlige. Ratene satt i fet skrift er signifikant forskjellige fra referansevariablene $(=1)$

\begin{tabular}{|c|c|c|c|c|}
\hline & $\begin{array}{c}\text { Opplevelse av } \\
\text { LAR }^{1}\end{array}$ & LAR-senter $^{2}$ & $\begin{array}{c}\text { LAR og } \\
\text { skadereduksjon }^{3}\end{array}$ & $\begin{array}{c}\text { LAR og } \\
\text { benzodiazepiner }\end{array}$ \\
\hline \multicolumn{5}{|l|}{ Kjønn } \\
\hline Kvinne & $0,79[0,57-1,10]$ & $1,08[0,79-1,47]$ & $1,12[0,82-1,53]$ & $0,96[0,70-1,32]$ \\
\hline Mann (ref.) & 1 & 1 & 1 & 1 \\
\hline \multicolumn{5}{|l|}{ Alder } \\
\hline 40 år eller yngre & $0.58[0,36-0,93]$ & $1,28[0,81-2,03]$ & $1,02[0,64-1,63]$ & $0,71[0,45-1,13]$ \\
\hline 41-55 år & $0,76[0,53-1,09]$ & $0,93[0,67-1,31]$ & $0,92[0,65-1,29]$ & $1,04[0,74-1,45]$ \\
\hline $\begin{array}{l}55 \text { år eller eldre } \\
\text { (ref.) }\end{array}$ & 1 & 1 & 1 & 1 \\
\hline Listelengde & $0,99[0,99-1,00]$ & $1,00[0,99-1,00]$ & $0,99[0,99-1,00]$ & $0,99[0,99-1,00]$ \\
\hline $\begin{array}{l}\text { Antall LAR- } \\
\text { pasienter siste år }\end{array}$ & $1,13[1,07-1,19]$ & $1,00[0,98-1,03]$ & $0,97[0,94-0,99]$ & $1,07[1,02-1,11]$ \\
\hline \multicolumn{5}{|l|}{$\begin{array}{l}\text { Henv. til spes. } \\
\text { rusbeh. siste år }\end{array}$} \\
\hline Aldri & $1,34[0,69-2,60]$ & $0,68[0,37-1,25]$ & $0,58[0,31-1,07]$ & $0,69[0,37-1,30]$ \\
\hline Noen få ganger & $1,22[0,69-2,17]$ & $0,81[0,48-1,39]$ & $0,58[0,34-1,00]$ & $0,66[0,38-1,15]$ \\
\hline $\begin{array}{l}\text { Månedlig eller } \\
\text { mer (ref.) }\end{array}$ & 1 & 1 & 1 & 1 \\
\hline \multicolumn{5}{|l|}{ Spesialiststatus } \\
\hline Ikke spesialist & $0,82[0,43-1,57]$ & $1,23[0,66-2,30]$ & $1,11[0,59-2,10]$ & $0,91[0,49-1,69]$ \\
\hline $\begin{array}{l}\text { Under } \\
\text { spesialisering }\end{array}$ & $0,88[0,57-1,36]$ & $0,73[0,48-1,11]$ & $1,25[0,82-1,89]$ & $0,96[0,63-1,46]$ \\
\hline Spesialist (ref.) & 1 & 1 & 1 & 1 \\
\hline \multicolumn{5}{|l|}{ Helseregion } \\
\hline Nord & $1,54[0,84-2,80]$ & $0,76[0,43-1,34]$ & $0,46[0,26-0,82]$ & $1,97[1,11-3,48]$ \\
\hline
\end{tabular}




\begin{tabular}{|lcccc|}
\hline & $\begin{array}{c}\text { Opplevelse av } \\
\text { LAR }^{1}\end{array}$ & LAR-senter $^{2}$ & $\begin{array}{c}\text { LAR og } \\
\text { skadereduksjon }^{3}\end{array}$ & $\begin{array}{c}\text { LAR og } \\
\text { benzodiazepiner }^{4}\end{array}$ \\
\hline Midt & $\mathbf{1 , 1 0 [ 0 , 6 3 - 1 , 9 1 ]}$ & $\mathbf{0 , 4 7}[0,28-0,81]$ & $\mathbf{0 , 4 2}[\mathbf{0 , 2 5 - 0 , 7 2 ]}$ & $0,60[0,35-1,03]$ \\
\hline Øst & $0,91[0,56-1,41]$ & $1,06[0,70-1,60]$ & $0,90[0,59-1,36]$ & $1,29[0,85-1,96]$ \\
\hline Sør & $0,94[0,57-1,56]$ & $\mathbf{0 , 4 0}[0,25-0,65]$ & $0,69[0,43-1,11]$ & $0,92[0,57-1,49]$ \\
\hline Vest (ref.) & 1 & 1 & 1 & 1 \\
\hline [i] & & & & \\
\hline
\end{tabular}

[i] ${ }^{1}$ Spørsmålet som er stilt: Hvordan opplever du å være LAR-lege?

${ }^{2}$ Påstanden som er stilt: LAR-senteret/spesialisthelsetjenesten er til liten hjelp

${ }^{3}$ Påstanden som er stilt: Legemiddelassistert rehabilitering dreier seg mest om skadereduksjon

${ }^{4}$ Påstanden som er stilt: Enkelte av mine LAR-pasienter trenger benzodiazepinpreparater

\section{Diskusjon}

En majoritet i dette utvalget av norske fastleger aksepterer LAR-modellen, slik undersøkelsene i 2000 og 2006 også viste (7.). Andelen negative er lav mens omtrent en tredel er nøytrale. Det er fortsatt en betydelig minoritet som er skeptisk til å være forskrivende lege i behandlingen. Denne andelen var $33 \%$ i 2006, og er i denne undersøkelsen på samme nivå.

Enkelte har ment at LAR-modellen er for tungvint (10 $)$ eller at allmennlegene kan overta en større del av ansvaret innenfor det tverrfaglige samarbeidet (11). Unders $\varnothing$ kelsen gir liten st $\varnothing$ tte til dette. Flertallet ser behov for tverrfaglig forankring og få ønsker å overta ansvaret alene. Den typiske LAR-legen finner det betryggende å arbeide innenfor et strukturert samarbeid med ansvarsdeling. Det er svært få som mener at spesialisthelsetjenestens rolle er til hinder for behandlingen, og nesten alle vurderer sosialtjenesten som viktig. Disse vurderingene samsvarer med hovedtyngden av evalueringslitteraturen som anbefaler samarbeid mellom spesialisttiltak og allmennleger (13)-(15). Undersøkelsen viser at legene har en nøktern vurdering av hva som oppnås gjennom legemiddelassistert rehabilitering, og mange mener at man mest oppnår skadereduksjon, dvs. at rehabiliteringseffekten er liten. Likevel er vurderingene i hovedsak positive. Implikasjonen er at mange leger aksepterer skadereduksjon som en relevant målsetting.

Mye av kritikken mot legemiddelassistert rehabilitering knytter seg til den høye vekten på kontroll og styring av behandlingen fra spesialistnivå $(\underline{10}, \underline{12}, \underline{16})$. Heller ikke dette finner mye støtte blant LAR-legene. Majoriteten mener ikke at kontrollen er for streng. Urinprøvekontroller har god tilslutning. Det er likevel en betydelig minoritet som mener at urinkontroller bør kunne erstattes med samtaler og personlig kontakt, og noen mener også at det bør være åpning for å forskrive benzodiazepiner. Nesten ingen støtter forslagene fra Stoltenberg-utvalget om fors $\emptyset \mathrm{k}$ med heroinassistert behandling (17.).

Ved spørreundersøkelsene i 2000 og 2006 hadde kjønn, alder og politisk orientering betydning for vurderingen av legemiddelassistert rehabilitering. I denne undersøkelsen er de politiske holdningene ikke tatt med, og demografiske forhold har liten betydning. Man kan spore en viss polaritet mellom yngre og mer restriktive leger på den ene siden og mer LAR-erfarne og liberale leger på den andre. Den typiske lege har behandlet ca. fem LARpasienter og er mest fornøyd med retningslinjene, mens de som har mye erfaringer ser ut 
til å ønske nyanseringer og oppmykninger i modellen. Dette kan være et utgangspunkt for å drøfte om noen fastleger, eventuelt med særlig skolering, bør kunne få en mer selvstendig rolle.

Meningene om enkelte sider av legemiddelassistert rehabilitering varierer mellom helseregionene. Mest positivt blir den vurdert i Sør- og Midt-Norge, hvor det er et mer aktivt samarbeid mellom allmennlegene og spesialisthelsetjenesten $(\underline{8}, 9$.). Dette kan oppfattes som en støtte til utbygging av legemiddelassistert rehabilitering som et samarbeid mellom allmennlegene og en spesialisthelsetjeneste med oppfølgingsansvar. Liknende erfaringer er beskrevet i Skottland, Australia $(\underline{18})$ USA $(\underline{13}, \underline{19})$ og Canada (므).

Det er dessuten en erfaring f.eks i Irland at allmennleger som gir substitusjonsbehandling

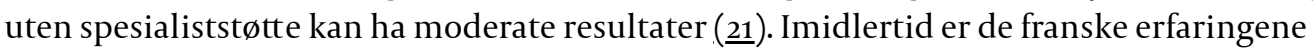
med allmenn forskrivning uten krav til opplæring og uten spesiell veiledning bedømt som positive selv om evalueringen i liten grad bygger på systematiske undersøkelser.

Kunnskapen om allmennlegers erfaringer er samlet vurdert nokså spinkel. Denne norske undersøkelsen er derfor et viktig bidrag.

På tross av fire purringer var deltakelsen i undersøkelsen relativt lav. Dette er en vanlig erfaring ved spørreskjemaunders $\emptyset$ kelser til leger $(\underline{22})$ og spesielt til allmennleger $(22,23)$.

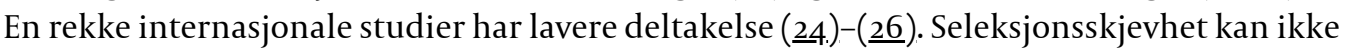
utelukkes, men funnene støttes av tidligere representative panelutvalg av norske fastleger (7.). Utvalget er dessuten representativt for norske fastleger når det gjelder kjønn, alder og listelengde. Funnene samsvarer dessuten med en undersøkelse av Alment praktiserende lægers forening fra 2002 (207.).

Det er en overrepresentasjon av LAR-leger i studien. Dette vurderes som gunstig, idet hovedhensikten er å undersøke hvilke erfaringer leger gjør ved å delta i LAR-behandling. Det er på dette området verdt å legge merke til at de LAR-legene som svarer i undersøkelsen, har behandlet mer enn halvdelen av alle LAR-pasienter som har hatt forskrivning fra allmennleger. Svarerne utgjør derfor et flertall av LAR-aktive leger. Det er mulig at leger med negative erfaringer med legemiddelassistert rehabilitering ikke har $\emptyset n$ sket å delta. Det bedømmes imidlertid som vel så sannsynlig at leger med klare meninger, både positive og negative, lettere motiveres til deltakelse, mens leger med mindre interesse og uten klare standpunkter kan ha latt være å svare. LAR-legene er dessuten representative for de legene som har deltatt, og disse igjen er representative for landets fastleger med henblikk på alder, kjønn og listelengde og skiller seg lite ut når det gjelder arbeidsmengde og geografisk tilhørighet.

Konklusjonen er at det i dette utvalget var liten opposisjon mot valget av samarbeidsmodell, selv om denne i noen grad innskrenker den enkelte leges autonomi.

LITTERATUR

1. WHO. Guidelines for the psychosocially assisted pharmacological treatment of opioid dependence. Genève: WHO, 2009.

2. Gurrik T, Haga W, Hole R et al. MAR I Norge - utvikling, utfordringer og perspektiver. Oslo: MARIO, 2002.

3. Hansen MB, Kornør H, Waal H. SKR-rapport nr. 7/2004. Bidrag til evaluering av Legemiddelassistert rehabilitering i Norge. Oslo: Seksjon for kliniske rusmiddelproblemer, Universitetet i Oslo, 2004.

4. Vindedal B, Steen L-E, Larsen B et al. Evaluering av legemiddelassistert rehabilitering. Rapport til Sosial- og helsedirektoratet. Oslo: Sosial- og helsedirektoratet, 2004.

5. Waal H. Merits and problems in high-threshold methadone maintenance treatment. Evaluation of medication-assisted rehabilitation in Norway 1998-2004. Eur Addict Res 2007; 13: 66-73. [PubMed] [CrossRef]

6. Helsedirektoratet. Nasjonal retningslinje for legemiddelassistert rehabilitering ved opioid avhengighet. Oslo: Helsedirektoratet, 2010. 
7. Aasland OG, Spilhaug G, Johannesen A. Fastlegers syn på legemiddelassistert rehabilitering og rusreformen. Tidsskr Nor Legeforen 2009; 129: 97-100. [PubMed]

8. Waal H, Clausen T, Håseth A et al. Statusrapport 2009. Siste år med gamle retningslinjer. Oslo: Senter for rus- og avhengighetsforskning, 2010.

9. Waal H, Clausen T, Håseth A et al. Statusrapport 2010. Første år med nye retningslinjer. Oslo: Senter for rus og avhengighetsforskning, 2011.

10. Haraldsen M. Behandling av opioidavhengige i allmennpraksis. Tidsskr Nor Lægeforen 2007; 18: 2706-7.

11. Skeie I, Brekke M, Lindbæk M et al. Allmennleger kan ta ansvar for legemiddelassistert rehabilitering. Tidsskr Nor Legeforen 2007; 127: 296-7. [PubMed]

12. Christie N, Syse A. Når Metadontilsynet forsvarer sine skanser. Aftenposten 1.1.2002.

13. Alford DP, LaBelle CT, Kretsch N et al. Collaborative care of opioid-addicted patients in primary care using buprenorphine: five-year experience. Arch Intern Med 2011; 171: 425-31. [PubMed] [CrossRef]

14. Kahan M, Wilson L, Midmer D et al. Short-term outcomes in patients attending a primary carebased addiction shared care program. Can Fam Physician 2009; 55: 1108-9, e5. [PubMed]

15. Weinrich M, Stuart M. Provision of methadone treatment in primary care medical practices: review of the Scottish experience and implications for US policy. JAMA 200o; 283: 1343-8. [PubMed] [CrossRef]

16. Frantzsen E. Metadonmakt. Møte mellom narkotikamisbrukere og norsk metadonpolitikk. Oslo: Universitetsforlaget, 2001.

17. Stoltenbergutvalget. Rapport om narkotika. Oslo: Helse- og omsorgsdepartementet, 2010.

18. Lintzeris N, Ritter A, Panjari M et al. Implementing buprenorphine treatment in community settings in Australia: experiences from the Buprenorphine Implementation Trial. Am J Addict 2004; 13 (suppl 1): S29-41. [PubMed] [CrossRef]

19. Samet JH, Friedmann P, Saitz R. Benefits of linking primary medical care and substance abuse services: patient, provider, and societal perspectives. Arch Intern Med 2001; 161: 85-91. [PubMed] [CrossRef]

20. Kates N, McPherson-Doe C, George L. Integrating mental health services within primary care settings: the Hamilton Family Health Team. J Ambul Care Manage 2011;34: 174-82. [PubMed]

21. Cullen W, Bury G, Barry J et al. Drug users attending general practice in Eastern Regional Health Authority (ERHA) area. Ir Med J 2000; 93: 214-7. [PubMed]

22. Flanigan T, McFarlane E, Cook S. Conducting survey research among physicians and other medical professionals. A review of current litterature. Alexandria, VA: Proceedings of the Survey Research Methods Section, American Statistical Association, 2008: 4136-47.

23. Aasland OG, Falkum E. Legekårsundersøkelsen. Tidsskr Nor Lægeforen 1994; 114:3054-8.

24. Bestmann B, Rohde V, Wellmann A et al. Zufriedenheit von Ärztinnen und Ärzten. Dtsch Arztebl 2004; 101: 28-32.

25. Joyce CM, Scott A, Jeon SH et al. The «medicine in Australia: balancing employment and life (MABEL)» longitudinal survey- protocol and baseline data for a prospective cohort study of Australian doctors' workforce participation. BMC Health Serv Res 2010; 10: 50. [PubMed] [CrossRef]

26. Shanafelt TD, Balch CM, Bechamps GJ et al. Burnout and career satisfaction among American surgeons. Ann Surg 2009; 250: 463-71. [PubMed]

27. Steinert S, Maartman-Moe K. Allmennlegens rolle i behandlingen av narkomanelegemiddelassistert rehabilitering. Tromsø/Oslo: Alment praktiserende lægers forening, Den norske legeforening, 2002.

Publisert: 4. september 2012. Tidsskr Nor Legeforen. DOI: 10.4045/tidsskr.12.0124

Mottatt 7.2. 2012, første revisjon innsendt 26.4. 2012, godkjent 21.6. 2012. Medisinsk redaktør Are Brean. (C) Tidsskrift for Den norske legeforening 2023. Lastet ned fra tidsskriftet.no 26. april 2023. 